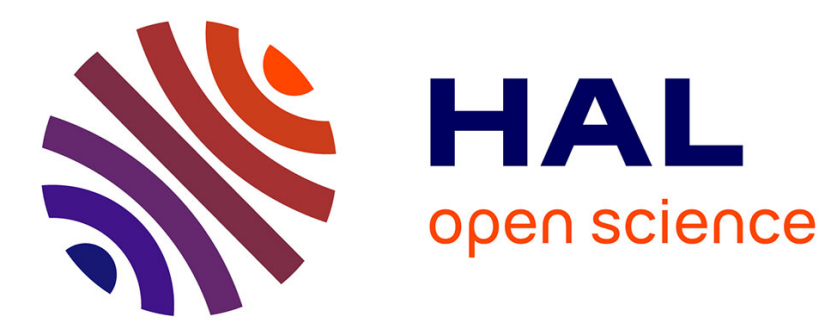

\title{
Respectability vs political agency: a dilemma for British radical societies \\ Rémy Duthille
}

\section{To cite this version:}

Rémy Duthille. Respectability vs political agency: a dilemma for British radical societies. Valérie Capdeville; Alain Kerhervé. British Sociability in the Long Eighteenth Century, 1, Boydell and Brewer Limited, pp.251-270, 2019, 978-1-78327-359-1. 10.1017/9781787444904.019 . hal-02405765

\section{HAL Id: hal-02405765 https://hal.science/hal-02405765}

Submitted on 11 Dec 2019

HAL is a multi-disciplinary open access archive for the deposit and dissemination of scientific research documents, whether they are published or not. The documents may come from teaching and research institutions in France or abroad, or from public or private research centers.
L'archive ouverte pluridisciplinaire HAL, est destinée au dépôt et à la diffusion de documents scientifiques de niveau recherche, publiés ou non, émanant des établissements d'enseignement et de recherche français ou étrangers, des laboratoires publics ou privés. 
Rémy Duthille

Plebeian societies, and especially the most famous of them, the London Corresponding Society, were a novelty and a defining feature of the political landscape of Britain in the 1790s. Those societies sprouted across London, the Midlands and North of England, and many Scottish towns and cities when the publication of Thomas Paine's Rights of Man (in two parts, 1791 and 1792) gave an impetus to reform movements and articulated a republican, anti-aristocratic, popular ideology. Drawing their membership largely but not exclusively among the disenfranchised artisan classes, popular societies agitated for a thoroughgoing reform of parliamentary representation, including universal manhood suffrage, annual (or very frequent) elections, a fair representation of cities, the abolition of rotten boroughs, pensions, sinecures and other forms or royal, aristocratic and government patronage. Though extraparliamentary politics existed before, and popular participation in political rituals such as elections was usual, and indeed expected, in England before the 1790s, the LCS and similar societies challenged the established order, as the initiative came from disenfranchised subjects. They were no longer expressions of a deferential political culture monitored by local élites, but posed a challenge to it. The government and conservative sectors of public opinion could not believe that mere artisans could set up political associations by themselves and they suspected that they were manipulated by aristocrats or wealthy individuals. In the history of political sociability, large popular societies are of interest because they tried, with a considerable degree of success, to devise democratic rules of procedure, to attract new members among the disenfranchised, and to educate them into citizenship. But those attempts at a democratic sociability were fraught with difficulties, because the norms of respectability - which were to be followed to be considered respectable, and by implication, worthy of the suffrage and a legitimate political opinion - constrained the radicals' room for manoeuvre, their agency. They were faced with the choice of adhering to middle-class norms in order to be taken seriously and earn their badges of citizenship, or to act up and flout conventions. The LCS, or at least its official instances and its authorized spokesmen, adopted the respectable strategy, a precarious one given that the context of war with France made the expression of deviant political expression more and more difficult, and, after December 1794, virtually untenable.

This chapter will start with a brief reminder of the history of the LCS, and a review of current historiographical trends which emphasize the rifts and contradictions in plebeian culture. The contention here is that there is a need to stress some aspects that were better 
captured in earlier accounts: the resilience of the society and its ability to follow viable rules. The LCS was able to build a bureaucracy even if its forms of sociability were enmeshed in contradictions of several kinds, which are explored in successive sections on respectability and social inclusiveness; the accommodation of plebeian and genteel codes of behaviour; the LCS's role as a school for citizenship, and finally the relationship, both symbolic and actual, between the LCS and official institutions.

I Historians and the paradoxical sociability of the London Corresponding Society

The starting point of Edward Thompson's The Making of the English Working Class was the foundation of the London Corresponding Society in January 1792. The story has become a familiar one: a shoemaker, Thomas Hardy, met with eight other like-minded artisans in a tavern off the Strand to discuss political writings, especially Thomas Paine's Rights of Man. All of them, save one, agreed to meet again the next week and subscribe one penny each to cover expenses for fuel, lighting, books and correspondence materials. Hardy soon devised rules, the first of which stating 'that the number of our Members be unlimited.' ${ }^{1}$ Thompson famously considered this rule as a fundamental break with exclusive elite politics, heralding a democratic project: it was no less than 'one of the hinges upon which history turns'. ${ }^{2}$ This rule and others, such as the rotation of members as chairmen of meetings, were meant to avoid any oligarchic tendency and ensure democratic debating and decision-making procedures. The society was open, in Thomas Hardy's words, to 'all classes and descriptions of men (criminals, insane and infants excepted). ${ }^{3}$ The same phrase was used in formulations of the society's main goals: the achievement of male universal suffrage and annual elections. The rules of the LCS, which regulated its pattern of sociability, were tightly linked to the society's democratic ideology. For instance, the equality of all members (corresponding to the equality of citizens in LCS ideology and to universal suffrage in its demands) manifested itself by rules such as the obligation for all members to speak during a given debate, or the rotation of the chairmanship, which were democratic practices meant to put in practice the ideal of equality and prevent any oligarchic or aristocratic tendency. It is therefore apt that Thompson should have started with a discussion of the procedural rules rather than with ideology.

\footnotetext{
${ }^{1}$ E. P. Thompson, The Making of the English Working Class (Harmondsworth: Penguin, 1980), p. 19.

2 Thompson, p. 24.

${ }^{3}$ Albert Goodwin, The Friends of Liberty: The English Democratic Movement in the Age of the French Revolution (London: Hutchinson, 1979), p. 192.
} 
The destiny of the $\mathrm{LCS}^{4}$ exemplifies the hopes and predicament of the English radicals who mustered the people to press for reform but failed to pass reform through parliament and finally fell victim of government repression and various forms of harassment on the part of selfstyle 'loyalist' associations. ${ }^{5}$ In 1792 and 1793 the LCS expanded rapidly and its infrastructure developed and ramified. It was divided into 'sections' that contained up to thirty members. Once this figure was reached a new section was created, and in this way a network grew across the boroughs surrounding the City of London and expanded eastwards. ${ }^{6}$ Besides organizing political readings, publishing pamphlets and corresponding with societies in Britain and the Jacobin club of Paris, much of the activity in the LCS in 1793 was concerned with the management of such an overgrown network; heated debated on the appropriate degree of autonomy or centralization led to the rejection of a 'constitution' that was deemed tyrannical.

Although many historians have studied the $\operatorname{LCS}^{7}$ and the chronology of its activities is well charted, some aspects of the society remain 'elusive' as Michael T. Davis wrote in his entry on the LCS in the Oxford Dictionary of National Biography. Contradictory claims were made about membership figures; it is safe to follow Davis's of a low point of 241 paying members in mid-1794 and a peak of 5000 men in 1795. What is known of the professional activity of a small fraction of the society suggests that artisans were most numerous but rubbed

\footnotetext{
${ }^{4}$ Accounts include: Michael T. Davis, 'London Corresponding Society (act. 1792-1799)', Oxford Dictionary of National Biography, Oxford University Press, 2004; online edn, Jan 2008; Goodwin; Selections from the Papers of the London Corresponding Society, 1792-1799, ed. Mary Thale (Cambridge; New York: Cambridge University Press, 1983); Michael T Davis, 'Introduction', in London Corresponding Society, 1792-1799, ed. Michael T Davis, 6 vols (London; Brookfield, VT: Pickering \& Chatto, 2002), vol. I.

${ }^{5}$ Loyalism spread across Britain in 1792-1793, then resurfaced under various guises (e.g. in the support for recruitment for the war). There is evidence of widespread popular participation far down the social spectrum, but historians are unsure whether the mass of loyalist propaganda distributed to the lower orders changed their opinions in the long run. See Robert R. Dozier, For King, Constitution and Country: the English Loyalists and the French Revolution (Lexington, KY: University Press of Kentucky, 1983); Mark Philp, 'Vulgar Conservatism, 1792-3', English Historical Review, 110 (1995), pp.42-69.

${ }^{6}$ On the geographical distribution of LCS sections, see John Barrell, 'London and the London Corresponding Society', in Romantic Metropolis: The Urban Scene of British Culture, 17801840, ed. James Chandler and Kevin Gilmartin (Cambridge ; New York: Cambridge University Press, 2005), pp. 85-112.

${ }^{7}$ The pioneering study was: Thompson. Subsequent studies and publications of primary sources include Thale; Benjamin Weinstein, 'Popular Constitutionalism and the London Corresponding Society', Albion: A Quarterly Journal Concerned with British Studies, 34.1 (2002), 37-57; Barrell, 'London and the London Corresponding Society'; Davis, I; Michael T. Davis, 'The Mob Club? The London Corresponding Society and the Politics of Civility in the 1790s', in Unrespectable Radicals? : Popular Politics in the Age of Reform, ed. Paul A Pickering and Michael T Davis (Aldershot: Ashgate, 2008), pp. 21-40.
} 
shoulders with members of the professions, medical doctors, lawyers, printers and publishers, who often played a key role in managing the society's activities. Beyond its fluctuating membership, the LCS was able to voice its message to a much larger audience, through pamphlets, a magazine, handbills and meetings. This was an uphill struggle. Self-styled 'loyalist' associations fought hard to eradicate the LCS, bringing economic pressure to bear on members and publicans who housed LCS meetings in their precincts. In May 1794, several members of the LCS were rounded up. Three leaders were indicted: Thomas Hardy, the founder of the society, the genteel reformer John Horne Tooke and the orator John Thelwall. Though the much-publicized treason trial resulted in acquittals, the society was reeling from the blow. It could still put on shows of strength, gathering monster meetings to protest against two bills meant to crack down on the liberty of assembly. ${ }^{8}$ On one such occasion, on 12 November 1794 , LCS leaders addressed a crowd of 300,000 to 350,000 athered in a field near Copenhagen House - an audience that went considerably beyond LCS membership. ${ }^{9}$ Popular agitation (such as several 'monster meetings' held in Sheffield, and, in London, by the LCS on 26 October and 12 November 1795 near Copenhagen House and on 7 December 1795 in Marylebone Fields) and parliamentary interventions failed to halt the passing of the Two Bills. From then on, the LCS started to decline because the liberty of association, petition and speech was severely curtailed; splinter groups of the LCS dabbled in underground revolutionary activity and the society was formally banned together with other societies in 1799.

The most remarkable fact about the LCS, however, is not so much its demise as its survival in the face of such odds. Following E. P. Thompson's insights, research carried out in the 1970s and 1980s by Günther Lottes and Mary Thale demonstrated that this resilience depended on the painstaking building of a viable society through procedures, and everyday administrative chores such as the collection of weekly dues, account-keeping and the management of correspondence and printing. Mary Thale insisted, quite rightly, that ' $[\mathrm{t}] \mathrm{he}$ orderly functioning of the Society - indeed their remarkable continuance for over six years -

\footnotetext{
${ }^{8}$ The Treasonable Practices Act (36 Geo III c.7) and the Seditious Meetings Act (36 Geo III c.8), variously known as the 'Pitt and Grenville Acts' or the 'Gagging Acts', became law on 18 December 1795. The first redefined and extended the existing law on treason and sedition. The second required magistrates to authorize meetings of more than fifty people, in effect criminalizing popular political meetings and outlawing LCS meetings. Inciting hatred against the king, the government or the constitution could be punished by transportation of up to seven years. On the legal and ideological background of the acts, see John Barrell, Imagining the King's Death: Figurative Treason, Fantasies of Regicide, 1793-1796 (Oxford ; New York: Oxford University Press, 2000).

${ }^{9}$ Goodwin, p. 391.
} 
owed much to the members' adherence to rules of procedure. ${ }^{10}$ Voting on a variety of issues (including on rules of procedure), rotation of offices, the choice of extracts to read out and discuss, debating rules such as the obligation of speaking in turn without breaking in on speeches, may have been more fundamental and more formative in the members' experience than any ideological content conveyed by the society.

Today historians of British radicalism ${ }^{11}$ in the 1790s pay close attention to sociability, but have largely moved away from Thompson's focus on class formation and his heroic narrative of the endeavours of stern, respectable, artisan, and later working-class societies. ${ }^{12}$ Since the mid-1980s, writing on the LCS has been informed by the linguistic turn, and postmodern scepticism about the stability of signifiers and the possibility of an ultimate assignation of meaning. Mark Philp stressed the fragmented nature of radical ideology, and the unstable, fissiparous character of a radical sociability that was fraying at the edges, and caved in under government repression, loyalist harassment and internal contradictions as the 1790s wore on. ${ }^{13}$

Three largely overlapping tendencies can be discerned in recent literature. In the wake of the English translation of Jürgen Habermas's Structural Transformation of the Public Sphere (1962, transl. 1989), a vast literature has been concerned with the emergence of 'plebeian', or

\footnotetext{
${ }^{10}$ Thale, p. xxvi. By far the most complete account of the LCS's rules of procedures is to be found in Lottes's untranslated monograph in German (Günther Lottes, Politische Aufklärung und Plebejisches Publikum: Zur Theorie und Praxis des Englischen Radikalismus im späten 18. Jahrhundert (Munich ; Vienna: Oldenbourg, 1979). The gist of the argument is accessible in English in an article by Lottes and in work by Geoff Eley: Günther Lottes, 'Radicalism, Revolution and Political Culture : an Anglo-French Comparison', in The French Revolution and British Popular Politics, ed. Mark Philp (Cambridge: Cambridge University Press, 1991), pp. 78-98; Geoff Eley, 'Nations, Publics, and Political Culture: Placing Habermas in the Nineteenth Century', in Habermas and the Public Sphere, ed. Craig J. Calhoun (Cambridge, MA; London: MIT Press, 1993), pp. 289-339.

${ }^{11}$ See in particular Jon Mee, Conversable Worlds : Literature, Contention, and Community 1762 to 1830 (Oxford: Oxford University Press, 2011); Ana M. Acosta, 'Spaces of Dissent and the Public Sphere in Hackney, Stoke Newington, and Newington Green', EighteenthCentury Life, 27.1 (2003), 1-27; John Barrell, The Spirit of Despotism: Invasions of Privacy in the 1790s (Oxford; New York: Oxford University Press, 2006); Micah Alpaugh, 'The British Origins of the French Jacobins: Radical Sociability and the Development of Political Club Networks, 1787-1793', European History Quarterly, 44.4 (2014), 593-619.

12 Thompson was careful to define the LCS as a 'popular Radical society' rather than a workingclass society (Thompson, p. 22).

${ }^{13}$ Mark Philp, 'The Fragmented Ideology of Reform', in The French Revolution and British Popular Politics, ed. Mark Philp (Cambridge: Cambridge University Press, 1991), pp. 50-77.
} 
'counter public spheres'. ${ }^{14}$ The concept of the public sphere was diffracted and pluralized into competing, internally contentious, and overlapping spheres. ${ }^{15}$

More recently, some researchers have focused on the way space informed sociability, articulating different scales ranging from micro-spaces (the layout of a particular room or a tavern such as the Crown and Anchor) to the urban environment of London and on to transnational networks. ${ }^{16}$ As David Featherstone argued, '[t] he LCS's political identities and practices developed in relation to various transnational networks' because they were shaped in international circulations, for example by adapting French republican practices and symbols (the most notorious was their self-styling as 'citizens') and in turn spreading practices to popular societies in America and elsewhere. (441)

Thirdly, interdisciplinary studies have taken their cue from Iain McCalman's foundational work on the 'radical underworld' of Spencean societies. Thomas Spence, a proponent of a utopian land plan involving democratic institutions and parish ownership of land, had many disciples who gathered in 'a loosely-linked, semi-clandestine network of political organisations, groups, coteries and alliances.' The Spencean underworld overlapped with the LCS and hovered in a 'fluid, ambivalent position', forming 'a long and intricate overlap between the allegedly separate spheres of 'respectability' and 'roughness". ${ }^{17}$ McCalman drew attention to the specific venues (Spencean taverns, 'free and easies', debating clubs), forms of sociability and ritual practices. Though debating clubs were vehicles for serious political and anti-religious argument, entertainment was an integral dimension of plebeian sociability. 'The ritual 'hullaballoo' of singing, toasting, chanting, and cheering' involved a high degree of theatricality: ritual behaviour in plebeian taverns was bound up with notions of male honour and competitiveness. 'Some Spenceans probably attended them for purely expressive purposes

\footnotetext{
${ }^{14}$ Jon Klancher, The Making of English Reading Audiences, 1790-1832, (Madison, WI, London: University of Wisconsin Press, 1987); Kevin Gilmartin, Print Politics: The Press and Radical Opposition in Early Nineteenth-Century England (New York: Cambridge University Press, 1996).

${ }^{15}$ For an overview of this historiography, see the introduction of Alex Benchimol, Intellectual Politics and Cultural Conflict in the Romantic period: Scottish Whigs, English Radicals and the Making of the British Public Sphere (Aldershot, England; Burlington, VT: Ashgate, 2010). ${ }^{16}$ Acosta; Ian David Newman, 'Tavern Talk Literature, Politics \& Conviviality' (Ph.D., University of California, Los Angeles, 2013); D. Featherstone, 'Contested Relationalities of Political Activism: The Democratic Spatial Practices of the London Corresponding Society', Cultural Dynamics, 22.2 (2010), 87-104.

${ }^{17}$ Iain McCalman, Radical Underworld: Prophets, Revolutionaries and Pornographers in London, 1795 - 1840 (Oxford: Clarendon, 1998), pp. 2-3.
} 
- to enjoy the social ritual and to experience a release of tensions.' ${ }^{18} \mathrm{McC}$ alman's book opened up a new field dubbed 'plebeian studies' by Anne Janowitz, with major books by Jon Mee, David Worrall, and Kevin Gilmartin among others. ${ }^{19}$

In 2000, John Barrell's extensive study of treason law, Imagining the King's Death, made an exemplary and highly influential use of literary analysis to probe the complex political and cultural landscape of the $1790 \mathrm{~s}^{20}$ Several cross-disciplinary case studies informed by literary analysis, sociology and anthropology have stressed fault-lines, fluid affiliations, and the transvaluation of signifiers. The radicals acted as wordsmiths and playwrights staging disruptive performances in various arenas of power. Coffeehouses, courtrooms, prisons such as the Old Bailey and Newgate became contested sites in which outrageous 'performances' were played out. ${ }^{21}$ The histrionic character of many radical leaders, which Thompson deplored, ${ }^{22}$ was now seen as a weapon of cultural and political destabilization. ${ }^{23}$ Much attention has been paid to clashes and incidents that occurred in the course of plebeian sociability, or when plebeian and polite codes collided. A case in point is John Thelwall's King Chaunticlere; or, The Fate of Tyranny. Published as it was in 1794, in the aftermath of Louis XVI's decapitation, this comic fable about the beheading of a tyrannical cock led to a trial in the course of which Thelwall and his publisher Charles Pigott used the legal conventions of the courtroom - the prosecutor was obliged to name King George III whenever he uttered the word 'Chaunticlere' - in order to elicit laughter and destabilize loyalist discourse. ${ }^{24}$ Another well-documented incident started

\footnotetext{
${ }^{18}$ McCalman, p. 121.

${ }^{19}$ Anne Janowitz coined the term in a review of David Worrall's Radical Culture: Discourse, Resistance and Surveillance, 1790-1820 and Jon Mee's Dangerous Enthusiasm: William Blake and the Culture of Radicalism in Studies in Romanticism, 32.2 (1993), 297-303. Kevin Gilmartin accepted this label for his own work. Gilmartin, Print Politics, p. 4.

${ }^{20}$ Barrell, Imagining the King's Death.

${ }^{21}$ Michael T. Davis, Iain McCalman, and Christina Parolin, Newgate in Revolution: An Anthology of Radical Prison Literature in the Age of Revolution (London; New York: Continuum, 2005).

22 'Citizen' Groves's 'speech was moving, if a trifle histrionic, in its sincerity' Thompson, p. 147.; Thelwall 'had a dash of the histrionic in his character" (149); there was an 'excess of the histrionic in Margarot's character' (139).

${ }^{23}$ James Epstein and David Karr, 'Playing at Revolution: British "Jacobin” Performance', The Journal of Modern History, 79.3 (2007), 495-530; John Barrell, “"An Entire Change of Performances?" The Politicisation of Theatre and the Theatricalisation of Politics in the Mid 1790s', Lumen: Selected Proceedings from the Canadian Society for Eighteenth-Century Studies, 17 (1998), 11-50.

${ }^{24}$ Barrell, Imagining the King's Death, pp. 104-5; Michael Henry Scrivener, Seditious Allegories: John Thelwall \& Jacobin Writing (University Park, PA: Pennsylvania State University Press, 2001), pp. 111-18; James Epstein, In Practice : Studies in the Language and
} 
with John Frost's scandalous toast calling the King 'a German hog butcher' in a coffeehouse, which again led to prosecution after Frost was overheard by a loyalist customer (or spy?). The case raised issues of respectability, the limits of acceptable speech, and the blurred boundaries between public and private spheres. The coffeehouse was an intermediate space between the public sphere and the private realm, a contested space where sociability could either develop, or, more likely in the $1790 \mathrm{~s}$, be monitored and thwarted by the government. ${ }^{25}$

This historiographical tendency culminated in a festschrift for Iain McCalman, aptly entitled Unrespectable Radicals ${ }^{26}$ In this collection, Michael T. Davis discussed the issues of the LCS's respectability on the basis of the Times's reviling of the LCS as a 'mob club'. Davis argued that the government and the conservatives did not merely try to uphold the established order, but sought to root out plebeian clubs by redefining respectability and thus labelling them as deviant. They instigated a moral panic to polarize society into the respectable loyalists and the unrespectable 'Jacobins', who must be marginalized and ultimately eliminated. ${ }^{27}$ While conservatives defined the LCS as unrespectable, i.e. inclined towards 'hysteria, excitable, disorderly and passionate, and given to fantasy', the LCS retorted with their own 'politics of civility', a symbolic code in which they defined themselves as respectable, or 'autonomous, rational, reasonable, self-controlled and sane'. In other words, The LCS 'needed to present itself as inclusive, autonomous, as a rule-regulated organisation based upon the principle of equality and rational deliberation in order to invert the political messages of loyalists' ${ }^{28}$ Reviewing the abovementioned coffee-house scandals, Davis spelled out a central paradox of LCS sociability: the tension between the necessary rules of self-restraint and the excesses provoked by an unruly tavern-based sociability. Taverns were key sites because they formed the organizational basis of the LCS, and they were central to artisan sociability: the society could build on this already-

Culture of Popular Politics in Modern Britain (Stanford (CA): Stanford University Press, 2003), pp. 99-103.

${ }^{25}$ James Epstein, “Equality and No King." Sociability and Sedition : The Case of John Frost', in Romantic Sociability: Social Networks and Literary Culture in Britain, 1770-1840, ed. Clara Tuite and Gillian Russell (Cambridge: Cambridge University Press, 2002), pp. 4361; Barrell, The Spirit of Despotism, chap. 2; Newman, pp. 3-13.

${ }^{26}$ Paul A. Pickering and Michael T. Davis, Unrespectable Radicals? Popular Politics in the Age of Reform (Aldershot, England; Burlington, VT: Ashgate, 2008).

${ }^{27}$ By 1792 'Jacobin' came to designate in England supporters of the French Revolution. The loyalists used it as a term of abuse against all English reformers, exploiting the French origin of the word serving to show the foreignness of radicals. The word also carried a connotation of atheism or religious heresy. Few reformers accepted it; John Thelwall was a notable exception. On the word 'Jacobin' and Thelwall: Scrivener, pp. 21-42.

${ }^{28}$ Michael T. Davis, p. 25. 
existing network to maintain and expand its membership. But rules for keeping the LCS respectable, and especially the ban on drinking and smoking, were in stark contradiction with traditional tavern sociability, thus causing tensions, and occasionally incidents when a member's personal agenda clashed with the society's rules.

II A democratic, inclusive sociability in search of respectability

Michael Davis's account of the LCS's stigma-management strategies is very illuminating and enriches Günther Lottes's earlier account of the contradiction between the rational-discursive ideal of the LCS and its grounding in unruly traditional culture. ${ }^{29}$ However, it tells one side of the story, that of the society's difficult relations with the outside world (especially the social-political elites) and the need for managing the society's public image. Seen from the point of view of the rank-and-file, however, the social benefits of membership probably offset the social stigma. The scandals dissected in recent historiography typically involved gentlemen reformers or déclassé intellectuals acting out in exclusive or socially mixed venues. Importantly for the study of LCS sociability, those incidents usually happened outside the meetings of the society rather than in the humdrum meetings of local sections. This intellectual intelligentsia did exist and it left many traces of its activities in print, manuscript and court records - far more than did rank-and-file LCS members. In linguistically-informed analyses focusing on print culture this very vocal minority is bound to attract a disproportionate share of attention and possibly eclipse the more mundane everyday working of the LCS. How representative were they of the several thousand artisan members of the LCS? While reformers who ventured in the world of print or engaged 'seditious' talk in mixed company could be harshly punished, the artisans who attended LCS meetings might go unscathed and enjoy the benefits of radical sociability.

This contrast raises the question of democratic inclusiveness at a time when sociability became increasingly stratified and compartmentalized. LCS meetings held up a promise of free, rational, and egalitarian discussion. Günther Lottes interpreted the society's ethos as a plebeian-democratic derivation of Habermas's Kantian ideal of the enlightened public sphere. ${ }^{30}$

\footnotetext{
${ }^{29}$ Michael T. Davis; Lottes, Politische Aufklärung Und Plebejisches Publikum.

${ }^{30}$ Lottes, Politische Aufklärung und Plebejisches Publikum.
} 
For the history of sociability, the LCS's insistence on social inclusiveness mattered because it went against a major trend that had started in the decades preceding the French Revolution, what Jon Mee called 'a broader historical process emptying out or segregating many of the mixed public places through which the vivifying conversation of culture had been perceived to be circulating.' ${ }^{31}$ Gentlemen's clubs became exclusive preserves and free speech in taverns and coffeehouses was threatened by constant monitoring by loyalist informers. The LCS, by contrast, offered social mixing in its meetings and this impacted the members' lives and prospects. As Mark Philp noted, involvement in reform politics had very different implications for the? members of different social classes. Gentlemen-reformers like Horne Tooke were most vulnerable to social stigma. Aristocrats could dabble in Jacobinism with relative impunity. Conversely, 'for people like [Francis] Place and [Thomas] Hardy, reform offered a more practical kind of emancipation or empowerment, together with a degree of social mobility. ${ }^{, 32}$ This sense of opportunity pervades the classic autobiographies of the LCS leaders. 'After his acquittal, in 1794, John Binns noted, Hardy opened a boot store in Fleet Street, London. The friends of Parliamentary Reform, and the Radicals, liberally patronized him, and he acquired considerable property. ${ }^{33}$ Francis Place, a breeches maker, retrospectively wished that he had exploited his position and connections in the LCS to expand his business. He was held back by the fear of being accused of making profit out of his position, but the LCS secretary, John Ashley, was 'less scrupulous' 34 according to Place, and gained many customers.

Yet Place recognized he derived some benefits, financial but mainly intellectual, from his involvement in the LCS. Ashley passed on to Place books from some rich customers' 'considerable collections' and the frequentation of men of superior abilities was an exhilarating experience that helped him engage in business more confidently. ${ }^{35}$ In retrospect, Place was satisfied with, not to say complacent about, the influence of the LCS: 'the moral effects of the society were very great indeed; it induced men to read books, instead of spending their time at public houses, it induced them to love their own homes, it taught them to think, to respect

\footnotetext{
${ }^{31}$ Mee, Conversable Worlds, p. 132.

32 Philp, 'The Fragmented Ideology of Reform', p. 73.

${ }^{33}$ John Binns, Recollections of the Life of John Binns: Twenty-Nine Years in Europe and Fifty-Three in the United States : With Anecdotes, Political, Historical, and Miscellaneous (Philadelphia, PA, 1854), p. 42.

${ }^{34}$ Francis Place, The Autobiography of Francis Place, 1771-1854, ed. Mary Thale (Cambridge: Cambridge University Press, 1972), p. 143.

${ }^{35}$ Place, pp. 42-43.
} 
themselves, and to desire to educate their children. ${ }^{36}$ In this statement, self-respect is intertwined with moral righteousness, abstinence, family life and a desire for social mobility for one's children.

Place's autobiography, a major source for the history of radicalism, is a good site to explore Jacobin 'respectability'. ${ }^{37}$ This retrospective account is notorious for its concern with respectability. As Mary Thale noted, Place never failed to remind his readers that his wife and himself tried to dress and act in respectable ways, and castigated those who did not.

If a preoccupation with respectability seems repellent to us, Thale proceeded, Place's autobiography may help us to understand how the significance of the word has changed. For us it is an external matter, the good repute which, rightly or wrongly, other people accord us. But for Place it was primarily an internal disposition, even though such externals as clothes may have helped create it. Respectability meant having a good selfimage, a sense of one's self as an important being. ${ }^{38}$

Thale went on to comment that for Place and likeminded artisans respectability was not a given but 'a hard-won and perilous acquisition.' ${ }^{39}$ Thale's comments capture what might have been the core of the experience of participating in the LCS for artisans and disenfranchised subjects: a process of building self-respect and agency, which in twenty-first century terms could be called empowerment.

Lack of respectability was a stumbling block, as Thomas Hardy was later to explain in his autobiography (published in 1832, ironically, the year of his death and of the passing of the Great Reform Act). Hardy explained that opponents of the radicals often asked

who was the founder of the Society [...]. The question was always evaded, because of the obscurity and unimportance in Society of the founder, and that it might be better esteemed by the public, and more respectable, agreeably to the received idea of respectability, and that they might attend more particularly to the object which the thing formed had in view. ${ }^{40}$

Hardy's low social origin - he was a shoemaker - diverted the public's attention from the professed goal of the society, parliamentary reform. Hardy distances himself from 'the received

${ }^{36}$ BL, Add MS 27, 808, fo.60, quoted in Lottes, Politische Aufklärung Und Plebejisches Publikum, p. 209.

${ }^{37}$ Place, p. 43.

${ }^{38}$ Place, p. xxi.

${ }^{39}$ Place, pp. $x x i-x x i i$.

${ }^{40}$ Thomas Hardy, Memoir of Thomas Hardy, Founder of, and Secretary to, the London Corresponding Society (London: J. Ridgway, 1832), p. 100 emphasis added. 
idea of respectability' ${ }^{41}$ which meant that the lower orders had no say in politics. Significantly the first occurrence of the word in the Oxford English Dictionary appeared in 1775, in the comments by Virginian Arthur Lee on the 'respectability' of petitions sent from Northern English cities to the Westminster Parliament concerning the coercion of the colonies. ${ }^{42}$

III LCS sociability: a school for citizenship and respectability

All this suggests that respectability was bound up with citizenship, and achieving a degree of it entitled a social group to voting rights and political representation. The radicals of the LCS thought that attendance to meetings and the respect of procedural rules would educate the artisans into citizenship while building up their self-respect. For Lottes, the process was fraught with difficulty because of contradictions between three factors: the LCS leaders' ideal of an educated, enlightened, autonomous citizenry (involving democratic decision-making and, inevitably, lengthy debates) was at odds with the need for operational efficiency (which meant there should be a strong central executive in the LCS to make quick, authoritative decisions), and with the immaturity of plebeian masses partaking in a traditional culture that valued rowdy pastimes and encouraged a degree of violence. Eley commented that the LCS also presumed the political maturity of the masses that it was intended to create: it was a chicken-and-egg situation. ${ }^{43}$

Admittedly, the reality of LCS meetings was much messier than Place's idealized retrospective vision, as Thompson, Lottes, Thale, and probably Place himself, knew full well. But the contradictions were not as intractable as Lottes suggested. He acknowledged that the LCS had to mould its political expression into plebeian forms of sociability so as not to alienate the masses, but he tended to present this accommodation as a constraint rather than an opportunity. (Lottes 1979, 337) The tavern-based culture of the London artisans possessed features that were conducive, rather than hostile to, the educational work of the LCS. As Jon

\footnotetext{
${ }^{41}$ Hardy, p. 100.

42 'respectability, n.' Oxford English Dictionary Online. Oxford University Press, September 2016. Web. 7 September 2016. The reference is to Arthur Lee, A Second Appeal to the Justice and Interests of the People, on the Measures Respecting America. By the Author of the First (London: J. Almon, 1775), p. $12 .$.

${ }^{43}$ Lottes, Politische Aufklärung Und Plebejisches Publikum, p. 336; Eley.
} 
Mee noted, some members of the LCS, like Place, clearly perceived the contradictions between rational ideals and traditional entertainment but others, including John Thelwall, Daniel Isaac Eaton and Thomas Spence, did not. ${ }^{44}$ Levity need not be incompatible with serious political argument; toasts and songs performed the function of community building, a crucial one in the case of a marginalized, repressed group. ${ }^{45}$ In a semi-literate world singing could also be a more efficient method of political sensitization than reading and discussing abstract texts; neither are the two activities mutually exclusive.

Rather than rejecting existing practices of artisan sociability, the LCS tried to build on them. True, some prominent members of the LCS, like Place, professed to hate tavern culture. But Place himself was heavily indebted to a pre-existing artisan sociability. Before he joined the LCS in June 1794, he had been involved in several artisan clubs. He became a leader in the Breeches Makers Society, a benefit club whose activities were akin to those of a trade union. 'He also formed a society of carpenters, a benefit club of journeymen plumbers; he 'drew up articles for several other clubs, and assisted in their formation, for all which [he] was paid.' 46 There is a clear continuity between Place's earlier activities and his rapid rise in the LCS. The skills he had acquired were precious in the management of the LCS. He was repeatedly elected to the position of chairman, which he described as a difficult one that involved keeping order and pushing business forward without offending members' sensibilities. Place immediately adds that it was later decided that the chairman should be elected for three months rather than every evening. ${ }^{47}$ At this point the constraints of bureaucratic efficiency were at odds with the democratic imperative, but a sensible compromise was found.

IV LCS sociability, a blueprint for a democratic citizenship borrowing from established parliamentary forms

\footnotetext{
${ }^{44}$ Jon Mee, 'Thomas Spence and the London Corresponding Society, 1792-1795', in Thomas Spence: The Poor Man's Revolutionary, ed. Alastair Bonnett and Keith Armstrong (London: Breviary Stuff Publications, 2014), pp. 53-63 (p. 59).

${ }^{45}$ Davis 2014, 123. See also Iain Newman's chapter on toasting in this volume.

${ }^{46}$ Place, p. 126.

${ }^{47}$ Place, p. 151.
} 
A final tangle of homologies and contradictions must be explored: the relationship between the LCS (as a bureaucratic and political structure) and official (national and local) representative institutions. The LCS had given itself rules meant to ensure fair debating, liberty and equality of speech, and a structure topped by a representative leadership. It claimed that those structures, and the mode of sociability they made possible - fair, orderly, democratic, 'manly' in the sense of bold and responsible - demonstrated the civic maturity of the people, and could be applied to the official representative institution, Parliament. In a sense, then, the LCS was functioning as a counter-parliament. Much of the its activity was engrossed with the business of running the society democratically, which suggests that debating rules, observing them and changing them if needed may have been as important as debating national political issues. A mode of sociability that made it possible for mechanics to debate political topics in an orderly way was by itself a rebuttal of loyalist depictions of democracy as mob rule or anarchy. John Barrell pointed out a tantalizing correlation between the geography of LCS divisions in London and the structure of local government. There were few divisions in the City, which was akin to 'a ratepayers' democracy' offering wide opportunities for political participation. Therefore, tradesmen may have felt less urgent need to vent grievances in the LCS than other men of similar social standing living in boroughs ruled by local oligarchies. Inhabitants of the City felt they were active citizens already, and significantly, despite low LCS activity there, the City protested against the Seditious Meetings Act. ${ }^{48}$ If Barrell's surmise is true, which is very plausible, then the LCS offered a much-needed opportunity for political debate to men of the lower and middling orders who felt entitled to citizenship.

There was a homology between the LCS as an unofficial arena and official institutions. For the loyalists and the government, the LCS was trying to usurp sovereignty, especially when it sent delegates to the Edinburgh British Convention in the autumn of 1793 (in the government's view the word 'convention' was indicative of a Jacobin plot). ${ }^{49}$ Perhaps they were

\footnotetext{
${ }^{48}$ Barrell, 'London and the London Corresponding Society', pp. 96-97.

${ }^{49}$ Loyalists claimed that the LCS and similar societies were part of a French Jacobin plot to prepare for an overthrow of the British state and/or a French invasion. The loyalists took the use of French forms such as the word 'convention' as evidence of such a plot. See e.g. this comment on the British Convention held at Edinburgh in November-December 1793 with delegates from across Scotland, Sheffield and the LCS: 'We have seen an assembly in the metropolis of Scotland, borrowing its name, its inflated jargon, its sanguinary measures, from the records of Gallic anarchy, and ready to erect the standard of revolt in the fields of happy Britain' (Dundee Repository, of Political and Miscellaneous Information, 13 December 1793, quoted in John D. Brims, 'The Scottish Democratic Movement in the Age of the French Revolution' (Ph.D., University of Edinburgh, 1983), p. 510.). However, it 'was probably not
} 
not so far off the mark: at least some English reformers considered the LCS as a microcosm, or a blueprint, of an ideal British democratic polity. This can be inferred from an 'anecdote of Thomas Paine' recounted by John Thelwall in The Tribune, a periodical based on his political lectures. The anecdote is worth quoting fully:

It was observed in company to Thomas Paine, that the British and Irish were naturally inclined to Monarchy; so much so, that in their convivial meetings they always had a toast master; and that if six of them went to a tavern to drink a bottle of wine, one would be put into the chair who would collect the bill and pay the waiter, and the rest would benefit by his attention.

Very true, Sir, says Paine, suppose your six men met every day to drink their bottle, and that they had no more and the chairman always took a pint to himself: They would soon contrive to drink without one; that is, if they were fond of wine, and had common sense. $^{50}$

A country could be run as a club. The people club together their resources in the form of taxes and spend them after a democratic decision-making process. The implication is clear: the LCS's orderly proceedings prove the viability of a democratic plebeian polity. Revealingly, 'Paine' counters a conservative argument that also posits a homology between tavern sociability and the English political proclivities. Indeed, the analogy was generally assumed and fought over: whether in the loyalist press, pamphlets, parodies or graphic caricature, conservative discourse in the 1790s always emphasized the 'disorder' and 'anarchy' which supposedly pervaded 'Jacobin' societies. ${ }^{51}$

The government had a stake in the failure of the LCS, while the LCS had to prove they could adopt procedures that were not those of Pitt's despotism. But ironically quite the reverse also held true to some extent: it was in the government's interest to keep the LCS going at least for some time, and the LCS took up some forms and procedures of the British Parliament even while criticizing it. A report on a division meeting will serve to illustrate these points. ${ }^{52}$ On

so intentionally provocative or not insidiously revealing of an intention to assume the status or powers of a French republican convention' (Goodwin, p. 302).

${ }^{50}$ The Tribune, a Periodical Publication, Consisting Chiefly of the Political Lectures of J.

Thelwall, ed. John Thelwall, I (London, 1795), p. 71.

${ }^{51}$ See e.g. loyalist stories about a Jacobin's intrusion wreaking havoc in an orderly English tavern, ending with the ejection of the outsider and the return to order: Kevin Gilmartin, 'Counter-Revolutionary Culture', in The Cambridge Companion to British Literature of the French Revolution in the 1790s, ed. Pamela Clemit (Cambridge: Cambridge University Press, 2011), pp. 129-44 (p. 137).

${ }^{52}$ Thale, pp. 181-82. 
June 9, 1794, Division 2 of the LCS debated the publication of resolutions in the press, under the chairmanship of 'Citizen' Groves. After 'a confused conversation' it was decided to publish ten thousand copies. 'A squabbling Conversation for an Hour \& an half ensued respecting the Order of putting the Motions'. It was finally decided to discuss the motions in the order that they were made, following the practice of the House of Commons. This decision (and many similar ones in other debates) gives credibility to Place's claim that ' $[\mathrm{t}]$ he forms of the house of Commons were as nearly as possible observed' in the LCS. ${ }^{53}$ The LCS experimented with procedures, and while adopting some French words, it also imitated the Commons in form and phraseology (the LCS meeting is 'called to order' by the chairman, much as the Commons is by the Speaker). This shows that English 'Jacobinism' was no mere French import, but rather experimented new forms of organisation and debated fresh ideas, be they of English or French revolutionary origin. The meeting went on:

A Citizen (who was a Visitor) was very warm - he said that the Movers did not understand their own Motions, and that they were all Stupid

He was called loudly to order, \& the Good Sense of the Division No. 2 was defended by Citizen Groves [...].

Groves 'charged the Author of the Calumnies on that Division with coming there for the express purpose of creating a Confusion.' Another member added that 'it would be a glorious triumph for Pitt and Dundas if they should learn of such a clamour and quarrelling amongst the Members'. ${ }^{54}$ LCS members knew they were monitored and this self-consciousness shaped their discourse and practices. The fear of infiltration by spies and agents provocateurs made it particularly difficult to manage visitors, because the necessity of opening the society to visitors and new members (if only to prove they were no conspirators) facilitated governmental and loyalist infiltration.

The supreme irony is that Groves was an informer. ${ }^{55}$ The narrative quoted above is taken from his report, which was included in the Treasury Solicitor's papers. ${ }^{56}$ During the division meeting, Groves found himself in the position of chairing a division meeting, keeping order, defending the honour of the society and expelling a troublemaker. If Pitt and Dundas read this report, they must have gloated indeed. It was in the government's interest to keep the LCS working as a bureaucratic institution, at least for some time. Of course, the government

\footnotetext{
${ }^{53}$ Place, p. 141.

54 Thale, pp. $141-42$.

55 Thompson, p. 147.

56 The National Archives, Kew, England, TS 11/954/3498.
} 
employed agents provocateurs in order to undermine the movement from within and provoke indictable behaviour for courts to punish. But the government probably gained even more by keeping the bureaucratic structure working. It was easier to monitor a clearly-defined society than a shadowy underground like the world of Spencean taverns. The society's official hierarchy made it easier to identify leaders, and the considerable archive it produced served as evidence for the sedition trials of 1794. The employment of agents provocateurs and the use of material produced by the LCS bureaucracy could thus substantiate the two apparently contradictory charges levelled by the government and loyalists: that radicals were a bunch of 'incendiaries' bent on causing 'confusion', 'tumult', 'anarchy', and that the LCS plotted to subvert the monarchy.

This chapter has tried to bring out some complexities of the specific kind of 'plebeian' sociability that managed to survive repression and harassment for a remarkable seven years in the London Corresponding Society. In the polarized atmosphere of the 1790s, clashes and scandals inevitably erupted, sometimes inside meetings, often in external venues. As recently dissected in remarkable studies, those incidents have shed invaluable light on the shrinking limits of acceptable behaviour and norms of political expression in the 1790s. They testify to the degree of hostility the LCS and other similar societies had to face. This level of aggression, in turn, stemmed from the seriousness of the challenge posed to the Ancien Régime. It was no mean objective, and no easy task, to maintain a democratically-run society when Britain was at war with France and 'French principles'. Such resilience could only be achieved thanks to LCS leaders' and rank-and-file members' stints of hard work of community building, but alongside painstaking administrative chores, ritual practices like drinking, toasting, and communal singing were also crucial. Those activities were no mere impositions from above of the prescriptions of a rational public sphere; many activities in the LCS were continuous with, rather than disruptive of, artisan sociability. If Place's trajectory is in any way representative of that of other, anonymous, members, then the LCS, opening its doors to wide sections of the London population and not just artisans, managed to instil some self-respect and selfconfidence by rejecting social stigma and redefining 'respectability'. This chapter suggested that debating, letter-writing, collective pamphlet-reading, the collection of dues and the many other practices was as significant as the ideology that was conveyed by the LCS. On the face of it, the society was a failure: it lasted a mere eight years and never achieved any of its political goals. Many of the debates that agitated it concerned procedures and self-discipline. Debating the order in which motions should be tabled, or discussing whether to follow the customs of the House of Commons might seem futile. On the contrary, this was no loss of time, no distraction 
from the LCS's goal, but an essential part of the process of political education and selffashioning of the members. The disciplining features of LCS sociability - attending weekly debates, waiting in turn to speak out, electing chairmen, performing various duties in rotation - must have had a transforming effect on the LCS members, at least those who attended on a regular basis. In the absence of a study of the life of a cohort of LCS members - an impossible task to perform given the state of sources - one can only speculate about the importance of this transforming effect. The autobiographies of Francis Place and of Thomas Hardy suggest, however, that radical sociability opened up business opportunities and occasions for intellectual advancement and the honing of social, organizational, oratorical and writing skills; for many members the entertainment provided in taverns must have also cemented bonds and friendships. All those skills and social relations that were enhanced by LCS sociability built up a man's agency in in the sense that he could get more professional opportunities and had more skills to grasp them. Thought this kind of self-advancement was not the goal of the LCS, it was a welcome result, building a sense of respectability and community that could be passed on to a new generation of reformers.

Bibliography

Acosta, Ana M., 'Spaces of Dissent and the Public Sphere in Hackney, Stoke Newington, and Newington Green', Eighteenth-Century Life, 27 (2003), 1-27

Alpaugh, Micah, 'The British Origins of the French Jacobins: Radical Sociability and the Development of Political Club Networks, 1787-1793', European History Quarterly, 44 (2014), 593-619

Barrell, John, “"An Entire Change of Performances?" The Politicisation of Theatre and the Theatricalisation of Politics in the Mid 1790s', Lumen: Selected Proceedings from the Canadian Society for Eighteenth-Century Studies, 17 (1998), 11-50

- Imagining the King's Death: Figurative Treason, Fantasies of Regicide, 1793-1796 (Oxford; New York: Oxford University Press, 2000)

_ ' 'London and the London Corresponding Society', in Romantic Metropolis: The Urban Scene of British Culture, 1780-1840, ed. James Chandler and Kevin Gilmartin (Cambridge ; New York: Cambridge University Press, 2005), pp. 85-112

- The Spirit of Despotism: Invasions of Privacy in the 1790s (Oxford ; New York: Oxford University Press, 2006)

Benchimol, Alex, Intellectual Politics and Cultural Conflict in the Romantic period: Scottish Whigs, English Radicals and the Making of the British Public Sphere (Aldershot, England; Burlington, VT: Ashgate, 2010) 
Binns, John, Recollections of the Life of John Binns: Twenty-Nine Years in Europe and FiftyThree in the United States : With Anecdotes, Political, Historical, and Miscellaneous (Philadelphia, PA, 1854)

Brims, John D., 'The Scottish Democratic Movement in the Age of the French Revolution' (Ph.D., University of Edinburgh, 1983)

Davis, Michael T, 'Introduction', in London Corresponding Society, 1792-1799, ed. Michael T Davis, 6 vols (London; Brookfield, VT: Pickering \& Chatto, 2002), I

, "Meet and Sing, and Your Chains Will Drop Off Like Burnt Thread": The Political Songs of Thomas Spence', in Thomas Spence: The Poor Man's Revolutionary, ed. Alastair Bonnett and Keith Armstrong (London: Breviary Stuff Publications, 2014), pp. 109-25

Davis, Michael T., 'The Mob Club? The London Corresponding Society and the Politics of Civility in the 1790s', in Unrespectable Radicals?: Popular Politics in the Age of Reform, ed. Paul A Pickering and Michael T Davis (Aldershot: Ashgate, 2008), pp. $21-40$

Davis, Michael T., Iain McCalman, and Christina Parolin, Newgate in Revolution: An Anthology of Radical Prison Literature in the Age of Revolution (London; New York: Continuum, 2005)

Dozier, Robert R., For King, Constitution and Country: the English Loyalists and the French Revolution (Lexington, KY: University Press of Kentucky, 1983)

Eley, Geoff, 'Nations, Publics, and Political Culture: Placing Habermas in the Nineteenth Century', in Habermas and the Public Sphere, ed. Craig J. Calhoun (Cambridge, MA; London: MIT Press, 1993), pp. 289-339

Epstein, James, “"Equality and No King.” Sociability and Sedition : The Case of John Frost', in Romantic Sociability: Social Networks and Literary Culture in Britain, 1770-1840, ed. Clara Tuite and Gillian Russell (Cambridge: Cambridge University Press, 2002), pp. 43-61

_ In Practice: Studies in the Language and Culture of Popular Politics in Modern Britain (Stanford (CA): Stanford University Press, 2003)

Epstein, James, and David Karr, 'Playing at Revolution: British "Jacobin” Performance', The Journal of Modern History, 79 (2007), 495-530

Featherstone, D., 'Contested Relationalities of Political Activism: The Democratic Spatial Practices of the London Corresponding Society', Cultural Dynamics, 22 (2010), 87104

Gilmartin, Kevin, 'Counter-Revolutionary Culture', in The Cambridge Companion to British Literature of the French Revolution in the 1790s, ed. Pamela Clemit (Cambridge: Cambridge University Press, 2011), pp. 129-44 
- Print Politics: The Press and Radical Opposition in Early Nineteenth-Century England, Cambridge Studies in Romanticism, 21 (New York: Cambridge University Press, 1996)

Goodwin, Albert, The Friends of Liberty: The English Democratic Movement in the Age of the French Revolution (London: Hutchinson, 1979)

Hardy, Thomas, Memoir of Thomas Hardy, Founder of, and Secretary to, the London Corresponding Society (London: J. Ridgway, 1832)

Klancher, Jon, The Making of English Reading Audiences, 1790-1832 (Madison, WI, London: University of Wisconsin Press, 1987)

Lee, Arthur, A Second Appeal to the Justice and Interests of the People, on the Measures Respecting America. By the Author of the First (London: J. Almon, 1775)

Lottes, Günther, Politische Aufklärung und Plebejisches Publikum: Zur Theorie und Praxis des Englischen Radikalismus im Späten 18. Jahrhundert (Munich ; Vienna: Oldenbourg, 1979)

- 'Radicalism, Revolution and Political Culture: An Anglo-French Comparison', in The French Revolution and British Popular Politics, ed. Mark Philp (Cambridge: Cambridge University Press, 1991), pp. 78-98

McCalman, Iain, Radical Underworld: Prophets, Revolutionaries and Pornographers in London, 1795 - 1840 (Oxford: Clarendon, 1998)

Mee, Jon, Conversable Worlds: Literature, Contention, and Community 1762 to 1830 (Oxford: Oxford University Press, 2011)

- 'Thomas Spence and the London Corresponding Society, 1792-1795', in Thomas Spence: The Poor Man's Revolutionary, ed. Alastair Bonnett and Keith Armstrong (London: Breviary Stuff Publications, 2014), pp. 53-63

Newman, Ian David, 'Tavern Talk Literature, Politics \& Conviviality' (University of California, Los Angeles, 2013) <http://search.proquest.com/docview/1369856734?accountid=14512> [accessed 15 July 2014]

Philp, Mark, 'The Fragmented Ideology of Reform', in The French Revolution and British Popular Politics, ed. Mark Philp (Cambridge: Cambridge University Press, 1991), pp. 50-77

—, 'Vulgar Conservatism, 1792-3', English Historical Review, 110 (1995), 42-69

Pickering, Paul A, and Michael T Davis, Unrespectable Radicals? Popular Politics in the Age of Reform (Aldershot, England; Burlington, VT: Ashgate, 2008)

Place, Francis, The Autobiography of Francis Place, 1771-1854, ed. Mary Thale (Cambridge: Cambridge University Press, 1972) 
Scrivener, Michael Henry, Seditious Allegories: John Thelwall \& Jacobin Writing (University Park, PA: Pennsylvania State University Press, 2001)

Thale, Mary, ed., Selections from the Papers of the London Corresponding Society, 17921799 (Cambridge; New York: Cambridge University Press, 1983)

Thelwall, John, The Politics of English Jacobinism: Writings of John Thelwall, ed. Gregory Claeys (University Park, PA: Pennsylvania State University Press, 1995)

- ed., The Tribune, a Periodical Publication, Consisting Chiefly of the Political Lectures of J. Thelwall, 3 vols (London: printed for the author, and sold at the lectureroom, Beaufort-Buildings: and by the following booksellers: D.I. Eaton, NewgateStreet: Smith, Portsmouth-Street, Lincoln's-Inn-Fields; and Burks, Crispin-Street, Spitalfields, 1795), vol.1

Thompson, E. P., The Making of the English Working Class (Harmondsworth: Penguin, 1980)

Weinstein, Benjamin, 'Popular Constitutionalism and the London Corresponding Society', Albion: A Quarterly Journal Concerned with British Studies, 34 (2002), 37-57 